\title{
東欧社会主義の崩壊と「現代史」 一ハンガリーのケースからー
}

南塚信吾

\section{はじめに}

第二次世界大戦後の世界史において重要な要 素となったのが、社会主義を揭げる体制がソ連 のみならず東欧やアジア・アフリカ・ラテンア メリカにまで拡大したことであろう。だが、戦 後のこの体制は、経済的に、あるいは政治的に 研究されることはあっても、歴史的研究の対象 となることはあまりなかった。しかるに、その 体制が崩壊してからようやく、それが歴史研究 の対象となりつつあるかに思光る。

さて、社会主義を揭げる体制がともかくも存 在したという歴史的事実は否定できないであろ う。この体制はまず無価值的には「現存社会主 義」と呼ばれるわけであるが、艺れをどう位置づ けるかという問題については、社会主義とみる もの、国家社会主義とするもの、あるいは国家 資本主義ないしは「開発独裁」とするものなどさ まざまである。最近の国際的な議論では、国家 社会主義とする議論が主流であるように見える。 しかし、「現存社会主義」の歴史的研究はまだこ れからであり、当面は「現存社会主義」の崩壊を 切り口にして、そこから進んでその歴史的研究 に向かうという傾向が見える。

本稿では、東欧を念頭において、「現存社会主 義」の崩壊の基本的な問題点を考え、そこから現 代史を考察するための視点を検討することにし たい。

\section{【1.「現存社会主義」}

「現存社会主義」を論ずるうえで、まず検討し ておかねばならないのは、I．ウォーラーステイ ンの「世界システム」論からする議論である。周 知のように、ウォーラーステインは、社会主義 を世界資本主義システムの一部として位置づけ ている。彼は世界システムにはひとつの原理し か機能しないと考えるから、世界システムのな かに資本主義と社会主義の原理が併存するとい うことはありえないとする。「16世紀」以来今日 まで、世界システムは資本主義の原理によって 支配されて扣り、社会主義と言わ机るものも、 資本主義的世界分業の一部なのである。ウォー ラーステインは、生産手段の国有や計画経済は 資本主義と矛盾しないと言う。1917年のロシア 革命は世界システムの「準周辺」から「周辺」へ のロシアの脱落を阻止するための革命であった。 また第二次世界大戦後の東欧への社会主義の拡 大も、アメリカのへゲモニーのなかで、それと 「連携した」形でのソ連による東欧掌握であり、 それによりアメリカの世界システムへのへゲモ ニーは安定したのである。したがって、1989〜 91年の東欧・ソ連の社会主義の崩壊も、アメリ カのへゲモニーの衰退の結果なのである。結局 彼によれば、社会主義は「社会主義世界システ ム」としてしかありえないのである。このような ウォーラーステインの議論は、最近東欧の左翼 から提起されている「国家資本主義論」につな 
がる議論のように思われる。

だが、筆者は、「現存社会主義」は、なんらかの 意味で資本主義とは異なった原理で動いていた体 制であったと考えている。これまで数回「現存社 会主義」のハンガリーやブルガリアに生活してみ た経験から、そこでの生産手段の私的所有の制 限、搾取の徹底した規制、所得の平準性、社会福 祉、そして協同の精神などは、資本主義のもとで は見られないものであったと考えるからである。

当面は国際的な議論に従って「現存社会主義」 を国家社会主義と考えておきたいと思う。以下、 社会主義と言うときは、国家社会主義としての 「現存社会主義」を意味することにする。

さて社会主義の現実的意義はどのように捉え られてきているだろうか。この点については、 これまでに、いくつもの論点が出されている。 経済面では、計画経済の利点、社会主義の下で の生活の物質的改善、つまり農業・農民生活の 改善、工業化による生産力の向上が指摘されて いる。さらに社会的平等・社会福祉という面も 注目されており、所得の平準化、女性の地位の 向上（特に労衝環境の整備）、高度の福祉などが 挙げられる。政治的には、「西」の形骸化した議 会制民主主義に詨して、直接的なソヴェト型の 民主主義が対置されたこともあった。国際関係 に扎いては、社会主義体制が「西」への対抗軸と なって、第三世界の対外的選択肢が拡大された ことも指摘されてきた。

もちろんここであげた利点もすべてが「白い」

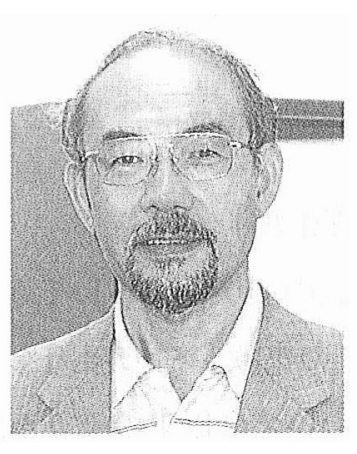

PROFIIE

南塚信吾

（みなみづか しんご 1942年生）

法政大学国際文化学部教授

専門：ハンガリー史、東欧史、国 際関係史

ものではなく、そこには多くの裏面があること も事実であり、せいぜい「灰色」程度であうう。

これに対して、社会主義の矛盾や問題点があ まりにも多く、露骨に「黒」として議論されてい る。1980年ごろまでは、(1)一党独裁による政治 的不自由、(2)国家・官僚制の支配、(3)国際的権 力（パワー）としての権力主義的行動、(4)経済 的硬直性、(5)個人の自己実現の機会の消滅、(6) 民族の抑圧などが指摘されていた問題であった。 だが、1980年代以後は、(7)環境污染を抑止でき なかったことや、(8)技術革新、情報化に対応で きなかったことが追加されてきた。いずれの点 も、特に社会主義体制にあってはならないとい う意味で「問題」とされたのであった。そして、 ここにあげた問題点も決してすべて「黒」という ことはなく、多くは「灰色」なのである。

こうして社会主義を「白」とも「黒」とも断定 するのではなく、E.H.カーや渓内謙氏らのソ連 史研究のように、社会主義の現実を徹底的に突 き詰めて、なおかつそこに社会主義のなんらか の現実的意義を見つけるという姿勢が必要なの ではないかと考える。社会主義が崩壊し、それ を支持する体制的イデオロギーが消滅したいま、 ようやくそういう現実的な歴史研究がしやすく なっていると思われる。 


\section{2. 東欧革命の原因}

\section{1）東欧革命の原因論}

では、社会主義の崩壞はどうしてもたらされ たのか。1989年の東欧鞈の原因をどう見る か。この崩壊については以下のような議論が出 されている。

第一に、国家社会主義の行き詰まりによる内 部的崩壊と見る議論がある。I.T.ベレンドやJ。コ ハノヴィッッに典型的である。ハンガリーのベ レンドは特に国家主導の経済の面での問題の集 積と見るのに対し、ポーランドのコハノヴィッ ツは経済的問題のほか、社会的な問題（たとえ ばパターナリズムの崩壊など）やイデオロギー 的正統性の垔失（マルクス主義はナショナリズ ムと福祉国家の理論で生き延びようとしたが失 敗した）を挙げている。

第二に、崩壊を極めて冷徹に「新冷戦」におけ る「東」の敗北と見る議論も重要な議論である。 軍事的詨立関係の拡大が国内の体制にまで及び、 崩壊に繋がったとするわけである。

第三に、同じく「外的」な要因を重視する議論 としては、イギリスのR.オーキーのように、崩 壊は自由主義の「幻想」が社会主義圈を取り巻い た結果であるとするものもある。リベラリズム の浸透とその裹切りといらコンテクストで論じ られている。

最後に、社会主義は時代によって乗り越光ら れたのだ、つまり国家の時代の終焉とともに 「国家社会主義」は崩壊したのだという和田春樹 氏らに見られる議論がある。

こうした観点から社会主義を見る研究はこれ
から実証的に行われなければならない。だが、 そのさい、筆者は素朴な疑問から出発せざるを 得ないのである。それは、1980年代の農村の安 定との関係である。

\section{2）社会主義下の農村と農業}

社会主義が崩壞した今日、東欧において最も 矛盾の出ている部門は農業と農村である。とこ ろが、1980年代の社会主義下の東欧の農村は、 比較的順調に発展していたのだった。そして、 かつての社会主義東欧については、農業と農村 がもっとも実証的な研究がなされていた分野で あった。先の成果から考学てみよう。

ハンガリーの農村の例をとれば、イギリスの C、ハーンは、長年のターズラール村の研究から、 社会主義の最後の10年間には、農業協同組合は それまでのどの時期に比べても、安定した発展 をしていたと言っている。同じくイギリスのN. スウェインもハンガリーの農村について同様の 見解を述べている。

筆者も、1980年代にハンガリーやブルガリア の農村をいくつも視察して、農業協同組合が生 産力だけでなく、生産の質の点でも、着実な発 展を遂げているのを確認したものであった。大 規模生産のみならず、個人的原理も導入され、 農民は、自己の保有する小さな菜園などを経営 することができ、そこでの生産には組合の品質 改良の成果をとりいれることができ、また生産 物は組合をとおして実現することもできていた。 もちろん、農業協同組合の幹部が農村で権力を 持って、問題を起こすということもあったが、 それは農村の体制を覆すような性格のものでは 
なかった。

また、筆者は、社会主義崩壊後の1990年代後 半に行ったハンガリー南部のボルダー二村の調 查からは、興味深い結果を得ている。農民たち にインタヴューしたところ、40\%ほどの農民は、 はっきりと1970～80年代の、カーダール・ヤー ノシュの時代が一番よかったと答えて、1990年 以後の協同組合の分割は理由がないと答えてい た。ちなみに、残りの30\%ほどは「分からな い、30\%は「変わらない」という答えであった。 戦前まで苦しんできた農民が、社会主義のもと で解放さ机安定した生活が送れるようになった ことは間違いがない。そして1980年代には、集 団的原理と個人的原理の併用で、農民は将来を 展望することもできていた。

東欧全体の視野に打いても、程度の差はあれ、 これは言えることで、イギリスの文化人類学者 R.アブラ八ムの編集した本でも執筆者たちは同 様の見解を述べている。

農村から考えるかぎり、どのように考えても、 1989年の「東欧革命」は説明できないのである。 そこに革命を引き起こす「矛盾」は見えない。農 村から見ると、革命はまずは都市、中央からや ってきたことになる。

\section{3. 東欧革命の内的要因}

\section{1）権力の変容}

では、社会主義の崩壊をどのようなメカニズ ムで説明するか。その一つの鍵となる議論とし て、ハンガリーの女性政治社会学者サライ・エ ルジェーベトの言う、権力エリートの変容とい
う視点がある。彼女は、社会主義のなかで権力 を持っていた層をノーメンクラトゥーラとし、 それが、政治権力から、経済権力そして文化権 力までを持つようになっていたとする。ノーメ ンクラトゥーラとは、社会主義時代の党の人事 「リスト」をさすが、さらにそのようなリストに 載るような指導的幹部要員という意味で使われ てきた言葉である。そのノーメンクラトゥーラ が、1980年代の世界的な資本主義経済のなか で、それと癒着するような経済的利害関係に入 り、その利害を実現するために社会主義の枠組 みを崩していった。そこに党の変質が生じ、 1989年の革命がもたらされた。事実その結果、 1989年以後すぐにノーメンクラトゥーラ・ブル ジョワジーが生まれることになったという。こ ういう権力エリートの革命論は、サライのほか、 左派の知識人に広がっている。

こうして、権力エリートの革命としておきた革 命が、農村をも覆ったと説明できるかもしれな い。しかし、都市と農村をなにが結んだのか。単 に党組織であるとは言えない。そこで考学なけれ ばならないのが、「市民社会」という言説である。

\section{2）「市民社会」言説}

この言説こそ、権力エリートを襲い、農村に まで浸透した言説なのではないか。この「市民 社会」論は、イギリスやフランスの 19 世紀を対 象とした近代の「市民社会」論ではない。後者 は、私的所有を基礎にし、法の前での平等など の権利を享受する市民を念頭においていた。こ れに対し、現代の「市民社会」は別の脈絡で出て きている。それは、1980年代の社会主義国の問 
題から由来している。つまり、国家と国家によ って管理された経済からの「脱却」としての市民 社会である。具体的には、1980年以後のポーラ ンドにおいて自主労働組合と教会の覆う社会が、 国家領域とは区別して意識され、そこを「市民 社会」として意味づける考えが現れたのである。 それが、西側世界にも受け入れられて、「市民社 会」論が展開され、国家権力から自立した政治主 体として市民が注目された。先の理論的な意義 はともかく、1989年にいたる時期の東欧には、 「市民社会」が社会主義に代わる価值を作り出し てくれるという言説が飛び交うようになった。 首都だけでなく地方でも只うであった。

こうして、権力エリートの革命は「市民社会」 論という言説を武器にして、東欧各国の中心か ら地方までを覆うことになったと思われる。

\section{3）社会主義の自己改革}

このような権力エリートの鞈をもたらした のは、戦後り連東欧に扔いて社会主義の自己改 革がなされなかったという歴史の結果である。 社会主義の自己改革という問題は、1950年代初 めからのユーゴスラヴィアに打ける「自主管理」 社会主義から見られるが、それは「破門」されて いた国での経験として扱われていた。ソ連東欧 社会主義圈の問題としては、少なくとも1956年 のソ連20回党大会を受けたハンガリー事件から 考えることができる。この時、ハンガリーでは ソ連型の社会主義の改革を目指したのであり、 改革派の綱領（多くは「第三の道」と考光られ た）にはその後問題とされるような諸点（複数 政党制、労働者評議会、自主労働組合など）が
ほとんどすべて含まれていた。これがソ連の戦 車によってつぶされてからは、ハンガリーのみ ならずソ連自体を含む社会主義陣営が硬直的に なり、その後の社会主義の自己改革の道を閉ざ していくことになった。社会主義陣営は1968年 の「プラハの春」を鎮圧し、1980年のポーラン ドの「連帯」を窒息させ、こうして柔軟かつ弾力 的に体制を自己改革していくことに失敗したの であり、結局それが1989年からの崩壊を招くこ とになったのである。

しかし、それでも、疑問は残る。どうしてこ の1980年代末に、崩壊が具体的になったのか。 これには世界史的な展望が必要である。

\section{4. 世界史のなかで——1980年代}

筆者は1980年代の世界史過程の結果として 1989年の東欧の崩壊とその後のソ連崩壊が州結 したという仮説を立てている。

1980年代の具体的な世界史の展開をまず見て みよう。1970年代後半にはアフリカとラテンア メリカに打ける社会主義は崩壊させられ、社会主 義として残るのは、ユーラシア大陸のそれのみと なっていた。だが、1979年に打ける三つの事件、 中越戦争、ソ連のアフガン侵攻、イラン革命が 80 年代に重大な意味を持った。中越戦争は社会主義 とアジアのナショナリズムへの幻滅を引き起こ し、ソ連のアフガン侵攻は「ベトナム」の道を歩 むり連社会主義への「抗議」を呼び起こし、イラ ン革命はイスラムの「権力」化を実現すると共に、 一方でソ連のアフガン駐留を長引かせ、ソ連内の 「アフガン問題」を深刻化させ、他方で、レバノオ 
ンを介して湾岸問題をパレスチナ問題と連動させ た。とくに「アフガン」はソ連の内部危機を深刻 化し、ペレストロイカを余儀なくし、東欧圈をふ くむり連の勢力圏の「放棄」につながった。ソ連 の指導者は1987年ごろにはハンガリーの指導者 に対して、もはや支援はできないと語っている。 そして、社会主義圈の崩壊はパレスチナ問題と連 動しつつ湾岸危機につながったのである。

上のような具体的展開の基礎には、1980年代 の世界史の構造的な動きがある。まず、世界経 済の面では1973年の石油危機以来の大きな構造 的変化があり、そのなかで結局多大な債務を抱 えたアフリカやラテンアメリカ諸国に1970年代 末以来 I M F 主導の「構造調整」が要求され、そ れが1980年代には東欧にも適用されるようにな る。この過程で、国家による経済の統制は放棄 され、多国籍企業というよりも超国籍企業とい うべきグローバルな資本が力を持つようになっ た。これはグローバリゼーションと呼ばれる過 程である。こうした過程を支えたのが、新たな 科学技術の発展であり、1970年代末から宇宙衛 星の発展などにより情報連絡が急速に進み、 1980年代からPCが普及し、IT革命が進展する にいたる。また、この過程を支えたイデオロギ 一として「ネオ・リベラル」が力を持つようにな る。そしてこれよりやや早く1970年代半ばから 「新冷戦」が開始されるのである。以上のような 基礎的な過程のうえで、1980年代の具体的な世 界史が展開したのである。

このような1980年代の世界的な動きのなか で、自己改革のできなかった社会主義世界に 「市民社会」の言説が浸透し、支配エリートによ
る社会主義への革命が行われたわけである。

\section{5. 現代史研究の課題}

筆者はこのような1980年代を現代史の重要な 転換期と考えている。1980年代の帰結として、 東欧とソ連の社会主義の崩壊と「冷戦」の終結、 そして湾岸戦争以降の中東の新展開があっただ けでなく、アメリカの「単独支配」が生じたので ある。では、改めてこの現代史はどのような要 素で特徴づけられるのか。ここでは、さしあた り二つの面から考えて执きたい。一つは、グ ローバリゼーションという問題であり、いま一 つは、人間の自分とその社会への意識の展開と いうことである。

\section{1）グローバリゼーション}

周知のとおり、グローバリゼーションという 「言葉」は1990年代に入って広がったものであ る。その後、グローバリゼーションという言葉 は広く使われて、言って見れば人間の歴史の過 程がずっとこのグローバリゼーションの過程で あったかのような見方が台頭している。果たし てそうであろうか。今はやりの歴史では、グロ 一バリゼーションは「大航海時代」に始まって いたとか、19世紀の末からの「帝国主義の時代」 にすでに見られたとか、1960年代の「国際化」 の時代がそうであったのだという見方が打ち出 されている。しかし、これでは、ずるずるべっ たりの史観になっていて、「現代」の特徴が見出 せない。やはり、グローバリゼーションと「国 際化」の違いは明確にすべきであろう。「国際 
化」は、なんといっても「国民経済」にまとめ られるものの障壁をいかに低くするかという過 程であった。しかし、グローバリゼーションは、 「国民経済」にまとめきれないトランス・ナショ ナルな経済の動きを持っている。ヘッジファン ドの動き、M＆ Aの国籍を問わ㜊開、国境を 問わないプロジェタト・ファイナスなど、「国民 経済」的なバランスを無視した活動は、「国際 化」では捉えきれない動きである。先れに伴っ て、社会、文化、価值観が「国民国家」を無視 して移動しているのである。上に挙げた「市民 社会」言説は、グローバリゼーションのイデオ ロギーの一つであった。

この過程は1980年代から始まり、90年代以 降、急速になっているが、当面は従来の「国際 化」と平行して進んでいる過程である。そして 当面、内容的には「アメリカ化」として展開し ている。このような過程を「現代」の特殊な要 素と考えていかねばならないのではないだうう か。このグローバリゼーションは東欧鞈を引 き起こした重要な要素の一つである。先述のよ うに、東欧社会主義のノーメンクラトゥーラを 市場化し、「ネオ・リベラル」の言説である「市 民社会」論を東欧に浸透させたのである。

だが、このグローバリゼーションの過程その ものも、まだ本格的な歴史研究の対象とはなっ ていない。このような時代にどうすればグロー バリゼーションに対抗した世界史的視野を持つ ことができるのだろうか。

\section{2）人間の自己意識}

この点にも関連して、現代の重要な問題と考
えられるのが、現代において社会を動かす守「」 はどこにあるのかという問題である。

かつて1960年代にE.H.カーはレーニン主義 の時代を「自己意識の時代」として、マルクスの 言う「土台」と「上部構造」の関係の変化を強調し ていた。マルクスの時代は経済の支配する時代 であり、レーニンの時代は政治の支配する時代、 言い換えれば「自己意識の時代」である。マルク スの時代は社会を動かす「効力」というものを 「多数の諸個人の自然発生的な行動の産物」と考 える時代であったが、レーニンの時代は、「効 力」というものを「意識的な政治的計画の差物」 として考える時代であった。その時代の特徴を、 レーニンはみごとに自分のものにすることがで きたというのである。

だが、カーは、「意識的な政治的計画」がどの ように形成されるかを見たとき、レーニンの時 代とスターリンの時代との違いを指摘した。レ ーニンの時代は、エリート集団の「意識的な政 治的計画」が大衆の期待と合致することが合理的 とみなされていた時代であるのに対し、スター リンの時代は、エリート集団の判断が合理的で あればよいとされる時代であると、両者の間の 違いを見ていた。カーは、レーニンの時代には、 政治諸勢力を指揮するエリートの指導は大衆の 意識性を目覚めさせ、その反応を絶えずフィー ドバックしているのに対し、スターリンの時代 には、エリート自身が合理的であるから、その 指揮も合理的であるとするという違いがあった としている。つまり、エリートの自己意識が大 衆によって点検されなくなるというのである。

では、1980年代以後のグローバリゼーション 
と情報化時代において、人間はどのように「自 己意識」を形成し、合理的で「意識的な政治的計 画」を生み出すのだろうか。それはどのように点 検されるのだろうか。現代に扔いては、「自己意 識」と言うべきものは、すべて政治操作の結果で あり、メディアの情報操作の結果なのではない だううか。1980年代に広がり始めたIT革命に支 えられた大衆の「自己意識」は、新たな質をもつ たものではなからうか。これは、大衆の自覚の いっそうの増大なのか、あるいは「無名の者」の 言説に踊らされる時代が来たということなのか。 「現代」は、これまでとはまったく違った人間の 社会を作り出しているように思われる。社会科 学や人文科学の発達により、人々は19世紀に比 べてはるかによくその社会や人間を知るように なっているはずである。だが、現実には、人々 は「言説」や「表象」に操られてしまっているよう に思われる。東欧革命はこの要素なしには説明 ができないのである。

だが、我々はまだ、現代の人々の「自己意識」 の様態について、これを歴史学の研究課題とす るには至っていないと言わねばならない。

$$
* * *
$$

我々はこのような現代において、グローバル 化した資本主義の持つ諸問題を乗り越える思想 と運動を考学る必要がある。人間疎外の克服と いう19世紀初め以来の問題はいまなお、いやい まいっそう深刻なものがある。その克服の営み を広く社会主義と呼ぶとすれば、現代において その社会主義はどのように構想されるのか。

社会主義には現在、処方嘎はない。社会主義 を構想するには、まず現実のグローバリゼーシ
ヨンに対抗して世界の全体像を回復することで あらう。現代の資本主義の新たな発達の結果を 人間はいかに全体として把握するか。この問題 を、現代資本主義の発達の矛盾を体現する者た ちの側から考え続けることしかない。

いま一つは、あらゆる情報や言説を問い直す 作業であり、それは我々が、我々に押し寄せて くる種々の「情報」や「意識操作」や「言説」を見 分け、現実を見極める力を養うという、地道な 「自己改革」の道である。

参考文献

Hann, Chirs, Tazlar, a village in Hungary, Cambridge UP., 1980

Simons, W. Thomas Jr., Eastern Europe in the Postwar World, Macmillan, 1991

Wallerstein, Immanuel, Geopolitics and Geoculture, 1991

Ibid., After Liberalism, 1995

Kideckel, A. David, East European Communities: The Struggle for Balance in Turbulent Times, Westview, 1995

Abrahams, Ray, After Socialism, Berghahm Books, 1996

Burawoy, Michael and Verdery, Katherine, Uncerntain Transition: Ethnographies of Change in the Postsocialist World, Rowman \& Littlefield, 1999

Kupferberg, Feiwel, The Break-up of Communism in East Germany and Eastern Europe, Macmillan, 1999

Swain, G. and Swain N., Eastern Europe since 1945 , Palgrave Macmillan, 2003

Okey, Robin, The Demise of Communist East Europe: 1989 in Context, Arnold, 2004

Minamizuka, Shingo ed., Legacies : of Socialism, Sairyusha, 2005

Szalai, Erzsebet, Socialism: An Analysis of its Past and Future, CEU Press, 2005

カー、E.H.『ロシア革命の考察』(南塚訳) みすず書房、 1969年

渓内 謙『スターリン政治体制の成立」第1-4部、岩波畫 店、1972-86年

南塚信吾『ハンガリーの改革』彩流社 1990年

和田春樹『歴史としての社会主義』岩波書店、1992年 